\title{
5:
}

\section{Bailando nace el Amor. El cortejo amoroso en el cine musical de Hollywood}

\author{
Gonzalo M. Pavés \\ Universidad de La Laguna (Tenerife)
}

RESUMEN

A través de la coreografía del cine musical, Hollywood ha expresado de forma sutil los sentimientos que afloraban entre sus personajes. Las canciones y el baile ofrecian al espectador una visión del amor que estaba estaba estrechamente vinculada con la concepción romántica que de él se ha construido en la cultura occidental desde el siglo $X I X$. Pero también los números musicales fueron aprovechados por los cineastas para representar e insinuar momentos del amor que, de otra manera, hubieran sido inaceptables y prohibidos por el Código Hays. Con el análisis de algunas de las secuencias de baile de las peliculas Sombrero de Copa, Un Americano en París y Grease, se describe en este artículo no sólo la puesta en escena del cortejo amoroso, sino también cómo su representación ha ido evolucionando a lo largo de la historia de los musicales producidos por Hollywood.

PALABRAS CLAVE: Hollywood/ Cine Musical/ Danza/ Claqué/ Amor

Love is born in Dancing. Sweetheart in Hollywood Musical Cinema

ABSTRACT

Through the coreography of musical cinema, Hollywood has expressed with fineness the feelings that flowed between the main characters. The songs and dance gave to the public a particular vision of Love that was intimately linked to the romantic concept the Western Culture has created since the nineteen century. But also the musical numbers of the genre were used by the filmmakers to depict and hint aspects of love that, if they were represents in an explicit manner, could be considered innaceptable by the Hays Code. With the analysis of some sequences from the films Top Hat, An American in Paris and Grease, the author of this article describe not only the mise-en-scene of the romantic courtship in the genre but the way its representation has developed throughout the history of Hollywood musicals.

KEY WORDS: Hollywood/ Musical Cinema/ Dance/ Tap Dancing/ Love

"Donde haya música, habrá canción Donde hay canto encontrarás un cielo azul Porque cuando todo el mundo marche mal Una sencilla cancioncilla Siempre traerá consigo un arco iris sonriente Con el arco iris, habrá risa Persiguiendo al sol en el cielo. Donde haya sol, habrá música Y donde haya música habrá amor".

("Where There' Music”, Judy Garland. Presenting Lily Mars, 1943).

Sin vida no hay cine. Es por esto que el arte cinematográfico, casi desde sus inicios, ha estado ligado directamente a la representación de lo real. No han sido

* PAVÉS, Gonzalo M.: "Bailando nace el Amor. El cortejo amoroso en el cine musical de Hollywood", en Boletín de Arte, $\mathrm{n}^{\circ} 29$, Departamento de Historia del Arte, Universidad de Málaga, 2008, págs. 455-480. 
pocos los debates teóricos que a lo largo de décadas ha suscitado la cuestión de si debía o no el cine estar maniatado a lo que es su materia prima más importante: la misma realidad. Desde las primeras proyecciones públicas, millones de espectadores no sólo han visto encarnadas sus vivencias cotidianas en la pantalla cinematográfica, sino que estas imágenes han condicionado sus actitudes y comportamientos. El cine ha moldeado los sentimientos, las ideas y las convicciones del público, que ha sido arrastrado hasta la oscuridad de las salas para mostrarle todas las experiencias vitales del ser humano, desde las más pequeñas y banales hasta las más decisivas y trascendentes. No se trataba tanto de la transposición fiel de la realidad, sino de sublimarla, idealizarla hasta tal punto, que los momentos más familiares quedaran transformados en sucesos extraordinarios.

También la realidad del amor ha interesado al cine. Las películas de Hollywood han reflejado de formas diversas la impetuosa floración de los sentimientos entre los protagonistas de sus películas. En casi todos los géneros cinematográficos, los encuentros y desencuentros amorosos han constituido el motor fundamental de sus argumentos. La pasión desatada por la primera mirada, los celos encendidos por la inquietante presencia de un tercero, el deseo nacido del leve roce de la piel y la amarga derrota escondida tras una traición amorosa han servido, una y otra vez, de excusa perfecta para construir las historias que encandilasen a los espectadores mientras sobrecogían sus corazones. Como todo en el cine, lo narrado sólo era un artificio, una ilusión que enmascaraba la realidad. Para los guionistas de Hollywood el amor en el cine era tan sólo un autómata de movimientos y reacciones previsibles. En la vida, sin embargo, el amor se mueve desatado, libre de complejos, se aferra a veces a detalles menudos, otras languidece y se apaga sin motivo o sin razón.

Pero en Hollywood ha dominado siempre una concepción romántica del amor. Nada hay mejor para el éxito de un filme que una buena historia de amor, aquella que se pone a prueba, en la que la pérdida o fracaso se presiente en cualquier esquina, pero donde al final, tras superar todos los obstáculos de la trama, los sentimientos terminan triunfando, pese a las desavenencias de los amantes, los intereses espurios, las diferencias de clase y la incomprensión familiar.

Más que en ningún otro género, el musical americano ha utilizado este esquema para levantar el habitual mundo fantástico que representaban sus tramas. Aquí los protagonistas cantan para demostrar sus sentimientos, dejan que sus cuerpos se muevan al son de la música, para expresar ese cosquilleo eléctrico que se siente cuando al ser humano alborota el amor. Da la sensación de que "los dos amantes protagonistas no consiguen juntarse por medio de los mecanismos fílmicos habituales del diálogo y la acción, pero cuando bailan juntos este impasse romántico se logra resolver. O puede ser que alguna emoción, profundamente disimulada, no pueda ser expresada a través de las vías dramáticas convencionales, pero sí mediante un baile, o más concretamente, una coreografía onírica. El baile puede llegar al rescate en estos o en otros casos, bien permitiendo que los potenciales amantes descubran sus verdaderos sentimientos mientras bailan, bien revelando mediante la imaginativa 
2: artículos Bailando nace el amor. El cortejo amoroso en el cine...

proyección de un baile lo que un personaje teme o desea en secreto"1.

En el cine musical, el baile es expresión del cortejo amoroso; el ritmo vertiginoso de las piernas de Fred Astaire o los delicados movimientos de Gene Kelly tratan de sublimarlo convertido coreográficamente en los rápidos latidos del corazón ante la presencia de quien se ama. Con el canto atraen a sus enamoradas; con la danza, los cuerpos se enlazan y hablan sin palabras, en el instante crucial los protagonistas encadenan a sus parejas en un movimiento frenético, casi báquico. Es el mágico momento de la consumación.

\section{AMOR Y DANZA.}

Como el amor, el baile ha sido siempre una parte fundamental de la vida de la gente corriente. En los albores de la humanidad era un acto social más en el marco de las ceremonias religiosas, de los rituales de fertilidad o de apareamiento. Para el pueblo, las danzas folklóricas eran un elemento imprescindible en la celebración de los acontecimientos sociales o familiares más relevantes; el nacimiento, la iniciación, el matrimonio, el acceso a un cargo o, incluso, la propia muerte eran arropados con ceremonias donde la música y el cimbreante movimiento de los cuerpos expresaban los sentimientos de alegría y tristeza de la comunidad. Juntas o separadas y, siempre en compañía de invitados, las parejas danzaban imbuidos de un profundo fervor religioso o simplemente movidos por un sencillo sentido lúdico de la vida. En la corte de nobles y reyes, las danzas, que eran aún más sofisticadas, ricas en protocolos y en preparados amaneramientos, hicieron las veces de punto de encuentro entre los sexos y espacio propicio para el cortejo.

A medida que el proceso de industrialización avanzó, los bailes vinculados con las actividades agrícolas y los ritos comunitarios se fueron perdiendo, pero aparecieron otros con nuevos fines y significados relacionados con las recientes circunstancias urbanas. La colonización europea, allí donde se dio, tuvo por otro lado, una enorme influencia en la evolución de la danza durante el siglo XIX. Se inició entonces un proceso de lenta fusión entre las danzas indígenas y los bailes de los colonizadores $^{2}$. A priori hubiera sido impensable que se produjese ese mestizaje de fórmulas; las diferencias entre las danzas europeas y las africanas, asiáticas y oceánicas eran notables. Así, por ejemplo, en las primeras se daba importancia a los esquemas de pasos, existía un cuidadoso ceremonial preestablecido, en el que se daba poco juego al movimiento de la parte superior del cuerpo. En las segundas, por el contrario, los movimientos no sólo implicaban a más partes del cuerpo (principalmente los brazos), sino que además se establecían diferencias entre sexos. Mientras los hombres podían golpear enérgicamente el suelo con los pies y ejecutar

1 DUNNE, M.: American Film Musical Themes and Forms. Carolina del Norte/Londres, McFarland \& Co, Inc. Publishers Jefferson, 2004, pág. 67.

2 Un buen ejemplo de ello fue la aparición del claqué o Tap dance, que fue el fruto del apareamiento de la danza y la Giga del Reino Unido con los estilos y movimientos del África Occidental. 
saltos espectaculares, los movimientos de las mujeres eran menos enérgicos, más delicados y elegantes, describiendo al danzar pasos mucho más pequeños y teniendo limitada la posibilidad de saltar o taconear.

La fusión, sin embargo, fue posible porque ambas culturas compartían un común denominador que hizo posible el cruce y el alumbramiento de formas nuevas en el baile. Como ocurría en la mayoría de las sociedades, debido a su origen popular, la mayoría de las danzas se construían a partir de un esquema que iba siempre de lo más sencillo a lo más complejo y que se articulaba a partir de movimientos bastante simples, compuestos de frases cortas y de dibujos que se repetían.

El papel social que la danza ha ejercido a lo largo de la historia ha sido, en esencia, siempre el mismo. Lo que sí ha variado, en especial a partir del siglo XX, es su difusión y su accesibilidad debido a los numerosos avances tecnológicos relacionados con la grabación y reproducción del sonido. Con el gramófono la gente pudo escuchar, por primera vez, música en casa que, a menudo, era bailable. El vals, el tango o el charlestón se popularizaron por todo el mundo fomentando el baile como una actividad social de la que se disfrutaba fuera de casa y de noche en salas de bailes, salones, discotecas o clubes. También la rápida difusión de la radio ofreció a un número mayor de personas la posibilidad de dejarse llevar por la música determinando así cierta democratización del baile 3 . Así mismo la irrupción del cine sonoro a finales de la década de los veinte se convirtió en un factor decisivo. Cuando el sonido llegó a las pantallas de las salas cinematográficas nació el cine musical y con él toda una época en la que el baile se va a presentar como un entretenimiento, quizá el más genuino, para el espectador 4 .

\section{CINE, AMOR Y DANZA EN EL MUSICAL AMERICANO.}

Nunca existió un cine en completo silencio. Desde sus comienzos el espectáculo cinematográfico estuvo casi siempre acompañado por el ruido y la música de una manera u otra. Aunque se tiene constancia de la producción de versiones mudas de algunas operetas y de que se llegaron a filmar escenas de danza que eran posteriormente proyectadas con acompañamiento orquestal, es obvio que sólo con la irrupción de la tecnología del sonido se favoreció la gestación y desarrollo del género musical. De alguna manera, El cantor de jazz (Alan Crosland, 1927) es un primitivo musical; en ella el silencio se rompe para dar paso a la voz, quebrada a veces, luminosa otras, de Al Jolson.

Con cierta rapidez el género evolucionó desde sus formas más arcaicas, representadas por las revistas musicales, hasta tipologías mucho más depuradas que finalmente se impusieron en las pantallas. En un primer momento, cuando los espectadores acudían al cine atraídos únicamente por el sonido, los estudios de Hollywood se limitaron a proponer una variedad de musical sin argumento y con la

3 DRIVER, I.: Un siglo de baile. Barcelona, Blume, 2001, pág. 7.

4 Aunque como bien señala Steven Cohan en su artículo introductorio del libro Hollywood Musicals, The Film Reader (Londres-Nueva York, Routledge, 2002, pág. 15): "Que se asuma que el musical, por ser un producto de estudio, era un simple entretenimiento, no significa necesariamente que fuera simple entretenimiento". 
rigidez visual propia de estos primeros años de transición del cine mudo al sonoro. Estas revistas cinematográficas se articulaban a partir de la yuxtaposición de números y actuaciones de diversa naturaleza que fueron "modeladas a partir del vodevil o de los más lujosos espectáculos de Broadway tales como las ediciones anuales de Ziegfeld Follies, (...), tendieron a hacer gala o a dar audición a las voces de las estrellas presentes y futuras del estudio"5.

Ya en la década de los treinta, cuando la nueva tecnología hubo superado todas las primeras dificultades de adaptación, el género musical evolucionó hasta dar lugar a unas variantes donde se ensamblaban, con mayor o menor fortuna, música, baile y argumento. A partir de esos años podemos distinguir dos modos dominantes: a un lado, tendríamos los backstage musicals o musicales entre bastidores, cuyos argumentos giraban en torno a la puesta en marcha de una obra, casi siempre musical, en un teatro de Broadway. En estas películas, los números musicales siempre se encuentran, desde un punto narrativo, perfectamente compartimentados y separados de la trama. "Esta separación no ocurre sólo especial o discursivamente, sino también económicamente, presentando [en los números musicales] un mundo de opulencia y exceso que contrasta con el mundo de las coristas que luchan por abrirse camino en los duros tiempos de la Depresión en los pasajes narrativos"6.

Al otro lado se encuentra una de las formas más evolucionadas, la representada por aquellas películas englobadas dentro de la categoría de musicales integrados. Concebidos como un todo, en ellos la letra de las canciones y la coreografía de los bailes pretendían integrarse con la narración; se buscaba el flujo ininterrumpido de la historia que no debía quedar en suspenso por la irrupción de un número musical. En ese sentido, y a diferencia de lo que sucedía con los anteriores, existe una mayor homogeneidad y continuidad entre el mundo de las actuaciones musicales y el discurrir narrativo. Es evidente que las fronteras no llegan a eliminarse del todo, pero quedan reducidas, suavizadas $^{7} y$, de esta forma, los números musicales contribuyen al desarrollo de la acción.

Precisamente esta asociación hace especialmente atractivo para nuestros objetivos esta modalidad de musical integrado, de larga y fructífera tradición, que engloba desde el ciclo de filmes protagonizados por Fred Astaire y Ginger Rogers para la RKO hasta Chicago (2002). En realidad todo el cine americano clásico vertebró o, al menos, apuntaló sus tramas a partir de la presencia del elemento romántico. El clásico esquema de la dramaturgia cinematográfica "chico conoce chica/chico pierde chica/chico recupera chica" demuestra que el motor de muchas historias no era otro que el amor. Esta necesidad de romance, intrínseca a la propia naturaleza del género, se vio considerablemente reforzada en el musical. En él, se reiteraba hasta el hastío el esquema anterior, puesto en evidencia a través de la música y el baile. Para la antropóloga Helen Fisher, en la medida que nos sentimos

\footnotetext{
5 Ibídem, pág. 5.

6 RUBIN, M.: "Busby Berkeley and the Backstage musical", en COHAN, S. (ed.): Hollywood Musicals, The Film Reader. Pág. 59

7 Ibídem.
} 
atraídos por otro, comenzamos a compartir un ritmo, y esta sincronía corporal no es más que una etapa del proceso humano del flirteo, una fase en la que los enamorados comienzan a moverse en espejo ${ }^{8}$. En el cine musical se aprovecha este carácter natural de la danza. El amor aparece adornado; se traducen sus impulsos, representado ahora en un nuevo lenguaje corporal, mucho más refinado y elegante.

Mientras que en los filmes de aventuras, de ciencia ficción o del oeste, los sentimientos estaban supeditados a la acción y la resolución de la historia se identificaba con la consecución de los objetivos anhelados por sus personajes principales, en el musical el triunfo, su cima narrativa y emocional, sólo se alcanzaba con el encuentro definitivo de la pareja protagonista. Cuando Fred Astaire actuaba con Ginger Rogers, su única meta era su compañera rubio platino. De este modo, el argumento se articulaba alrededor de las diferentes etapas de su estrategia seductora, en la que jugaban, sin lugar a dudas, un papel fundamental los números musicales. Astaire desplegaba en ellos todas sus habilidades y encantamientos para forzar la rendición de su deseada fortaleza.

En esta tipología de musical, la integración favorecía la utilización de los medios expresivos de la música y del baile para prolongar o exteriorizar las emociones de los personajes. Las evoluciones de los protagonistas no sólo ilustraban, también determinaban, modelaban o encauzaban sus sentimientos. Por esta razón resulta tan interesante la representación del cortejo amoroso en estas películas.

La danza es un arte, una forma bella de transmitir y expresar emociones humanas. En muchas ocasiones, por medio del baile, se ponen de manifiesto los impulsos naturales, de modo que no sólo se puede leer como una estilización del proceso de conquista, del cortejo romántico, sino también del propio encuentro sexual. No escapó al Código Hays esta relación. Los censores de Hollywood lo tenían muy claro y por eso se prohibía taxativamente:

"Las danzas que sugieren o representan actos sexuales, ejecutadas por un solo bailarín o por dos o más personas, y las danzas concebidas para excitar la reacción emocional del público, así como las que incluyen movimiento de los pechos o excesivos movimientos corporales con los pies fijos (1930)".

Pese a estas restricciones, el musical elaboró todo un repertorio de formas y recursos que, con sutileza, logró vehicular la pasión amorosa a través de la danza. "Los hechos de la vida son tales que ciertos procesos, ciertas actividades nunca desaparecen, sino son simplemente desplazadas hacia acontecimientos menos llamativos, menos evidentes (lo cuales, por el hecho de ser versiones desplazadas de algo más, conservan una cualidad simbólica). Este es un proceso sin final, activo en todos

8 "En toda sociedad donde hombres y mujeres pueden elegir libremente a sus parejas, los solteros se conocen en fiestas o festivales y bailan. ¿Y qué es el baile sino gestos rítmicos, movimientos corporales en espejo?" FISHER, H.: Anatomía del amor. Historia natural de la monogamia, el adulterio y el divorcio. Barcelona, Anagrama, 1994, pág. 27. 
los países y en todos los tiempos, pero que es particularmente sobresaliente en los Estados Unidos de América, donde la legislación sobre la moralidad es la norma" 9 .

En este punto sería pertinente, preguntarse qué clase de amor muestra este género cinematográfico. Es evidente que presenta una realidad transfigurada, una bella falsedad. El musical tiene algunos rasgos que permitirían englobarlo dentro del género fantástico ${ }^{10}$. Su realidad es "imposible", en sus argumentos se construye un mundo paralelo donde los diálogos son sustituidos por música, canciones y bailes a través de los cuales se expresan las emociones. "El género musical constituye algo así como un caso especial dentro del cine clásico narrativo porque se fundamenta en una contradicción esencial entre el discurso de la narración y el discurso de, al menos una parte significativa, de los números musicales. La narración y los números musicales parecen estar basados en diferentes leyes y normas básicas. Esta contradicción nunca (o en el mejor de los casos, lo hace débilmente) llega a ser resuelta en el musical (...)"11.

Los musicales, nacidos en plena Depresión, fueron concebidos por los productores y consumidos por los espectadores como piezas de puro entretenimiento. En aquellos años soslayar, aunque tan sólo fuera por unas horas, la depauperada realidad era un necesidad y el cine en general, pero el musical en particular, ofrecía la "imagen de algo mejor con lo que evadirse, o algo a lo que se aspira profundamente y que la vida cotidiana no ofrece. Alternativas, esperanzas, deseos..., estos son los materiales de la utopía, la sensación de que las cosas pueden ser mejores, de que algo distinto a lo que es puede ser imaginado y quizá realizado"12.

En cierto modo, el cine en general y el musical en particular es continuador del amor cortés medieval ${ }^{13}$. Como ocurre en el amor cortés, el amor fílmico es de hecho un embellecimiento. El deseo, la pulsión sexual se estiliza, se sublima hasta quedar oculta detrás de un ritual aceptado por la comunidad. Así las formalidades del amor romántico no son más que una etiqueta social que trata de enmascarar el origen primario, animal de algunas de las emociones más básicas. En el género musical estas convenciones se traducen en bailes, canciones y movimientos corporales que persiguen separar, o si no, al menos purificar, la lujuria de su evidente carnalidad.

En el cine clásico de Hollywood rara vez las historias iban van más allá del proceso de conquista, por eso se construían las tramas en torno al coqueteo, el idilio y el deseo no correspondido. Además del cortejo, esa energía reprimida también se podía ver representada en el cine de otros modos. Esa incapacidad de la sociedad de reconocer abiertamente la importancia que tiene la sexualidad determina, a juicio de Rick Altman, que el deseo sexual se vea desplazado y expresado por otros medios sustitutivos. Así la fascinación que despierta en el ser humano el misterio, el

9 ALTMAN, R.: The American Film Musical. Bloomington, Indiana University Press, 1989, pág. 159.

10 GONZÁLEZ, R. J.: "El musical como género fantástico, en Rosebud, n 3-4, La Laguna, Diciembre 1993, pág. 75.

11 RUBIN, M., op. cit, pág. 57.

12 DYER, R.: "Entertainment and Utopia", en COHAN, S. (ed.): op. cit., pág. 20.

13 Especialmente interesantes son las obras: MARKALE, J.: El amor cortés o la pareja infernal. Palma de Mallorca, Medievalia, 1998; AA. VV.: El arte de amar en la Edad Media. Barcelona, Medievalia, 2000. 
crimen y la violencia es innegable, hasta el punto de que en ocasiones el propio cortejo amoroso se tiende a concebir en términos de confrontación y conflicto de deseos y voluntades ${ }^{14}$.

Vigilados de cerca por la Oficina Hays, la representación del encuentro físico entre dos amantes estaba taxativamente prohibida. Si aparecían las caricias, podían ser esbozadas, incluso podían llegar a ser tiernas, pero en todo caso debían ser escrupulosamente castas. No había concesiones ante los besos; éstos estaban regulados de forma estricta: no podían ser ni prolongados, ni profundos, así como tampoco dados o recibidos en posición horizontal. Se sobreentendía que en el matrimonio existía el lógico y sagrado ayuntamiento, pero en los filmes donde la pareja romántica era el motor de la narración la trama nunca llegaba más allá del altar. Si la amada cedía finalmente, el público sabía que la conclusión del relato era inminente. No habría descripción de la noche de bodas, ni día después. El interés narrativo llegaba hasta ahí; no había emoción tras haber conquistado la prenda tan celosamente custodiada.

Como ocurría con otros géneros, en el musical tampoco se esperaba que el caballero poseyera realmente a su dama. Pero, quizá por su ligera naturaleza, la censura no actuó sobre él con la misma severidad. Más pendientes de lo evidente que del juego sutil de las metáforas, los guardianes de la moral cinematográfica se mostraron más relajados, tal vez más ciegos, ante la sensualidad hábilmente camuflada en algunos números musicales.

Esta conexión entre represión moral impuesta por el Código Hays y las formas de representación del cortejo en las escenas de danza del cine musical de Hollywood permite establecer tres momentos atendiendo, grosso modo, al estilo del baile, al tipo de música y a la mayor o menor carnalidad en la presentación del acto sexual. Coincidiendo con la imposición de la censura en Hollywood, distinguiríamos una primera época, dominada por el claqué, el swing y las composiciones de Irving Berlin, George Gershwin y Cole Porter. En esta etapa se alcanza el mayor grado de sublimación, el cortejo amoroso es aquí burbujeante, etéreo, vaporoso. Cuando a mediados de los años 40 , el claqué es sustituido por una forma de baile más expresiva resultado de la mezcla del jazz, con los bailes étnicos y de salón, pero también con el folk y el ballet, entonces las metáforas se tornan algo más evidentes, las coreografías se contonean expresándose ya en ellas una mayor carga erótica. La abolición del Código Hays a finales de la década de los sesenta marcó un último tiempo en el que, la irrupción del pop y el rock en el musical, hizo que se explicitase lo que antes estaba enmascarado y donde una pulsión sexual más diáfana y clara se convirtió en motor e inspiración de danzas y canciones.

\section{EVOLUCIÓN EN LA REPRESENTACIÓN DEL CORTEJO.}

En Estados Unidos, la década de los treinta estuvo marcada por la Gran

14 ALTMAN, R.: op. cit., págs. 159-160. 
Depresión. El hambre y el desempleo se extendieron por todo el país, y los teatros cinematográficos se convirtieron en verdaderas válvulas de escape, en lugares donde guarecerse de una realidad amarga y descorazonadora. "De hecho, todo el mundo veía películas durante la Depresión. El cine fue reconocido como una necesidad por la administración Hoover que, en medio de la crisis, distribuyó alimentos, ropa, y entradas para el cine. Estas entradas mantenían a la gente alejada de las calles y les ofrecía refugio y confort; el gobierno, en cierto sentido, estaba ofreciendo panem et circenses"15. Cobijados en las salas, reclinados en las butacas, los espectadores encontraron, por unos pocos centavos, un medio para hacer volar su imaginación y vivir la vida de otros durante el tiempo que durase la proyección.

El nacimiento del musical coincidió con la crisis económica derivada del Crack. Los beneficios obtenidos en taquilla son un indicador de la popularidad que alcanzó el género durante estos años. Los musicales, especialmente aquellos interpretados por Fred Astaire y Ginger Rogers para la RKO, conscientemente eludían la sombría realidad de la época. En cualquiera de las películas que protagonizaron los problemas sociales ni siquiera eran un telón de fondo, quedaban relegados al olvido para situar al espectador "en un mundo fantástico de lujo, elegancia y romance, donde la gente se pasa la vida en traje de etiqueta y de fiesta toda la noche"16.

Entre 1933 y 1939, el tándem formado por Astaire y Rogers se ganó el favor del público protagonizando algunas de las comedias musicales más importantes de la Historia del Cine. Frente a la atmósfera contaminada por la Depresión que se respiraba en los musicales entre bastidores, coreografiados por Busby Berkeley para la Warner, películas como Sombrero de Copa, En alas de la danza o Sigamos la flota eran siempre ligeras y luminosas, al tiempo que definían los elementos más característicos del musical integrado. "Aunque Astaire y Rogers, en sus películas, hicieron, además de bailar, muchas otras cosas (...) fue el baile lo que hizo que el público los adorase y lo que les permitía identificar sus estados de ánimo; la profundidad de sus sentimientos y su exquisita armonía sexual hacían de ellos no solo la pareja de baile ideal sino también la pareja romántica ideal. Ningún otro bailarín alcanzó mayor popularidad, y el hecho sorprendente es que Astaire y Rogers, cuyas escenas de amor eran sus números de baile, se convirtieron en la pareja más famosa que el cine ha conocido jamás"17.

Desde el punto de vista del baile, los años treinta fue un período dominado por el claqué. Al igual que el jazz era fruto de la síntesis de tradiciones diversas, el claqué era una modalidad de baile mestiza. Durante las tres primeras décadas del siglo XX fue el tipo de baile más popular producto en algún momento del lejano pasado, quizá en los tiempos de la colonización americana, de la fusión de "los pasos de baile europeos, como la gigas irlandesas y las danzas con zuecos de Lancashire, con las

15 MUSCIO, G.: Hollywood's New Deal, Philadelfia, Temple University Press, 1997, pág. 65.

16 BALIO, T.: Grand Design. Hollywood as a Modern Business Enterprise (1930-1939), Nueva York, Charles Scribner's Sons, 1993, pág. 218.

17 CROCE, A.: The Fred Astaire and Ginger Rogers Book, Nueva York, Galahad Book, 1972, pág.5, cit. BALIO, T.: op. cit., págs. 218-219. 
exaltadas y circulares danzas que los esclavos trajeron consigo de África"18.

Esta naturaleza dual nos permite explicar, en otro plano, la forma en que el cortejo se ha expresado musicalmente en el cine. En el baile, el elemento europeo vendría representado por una danza más racional, más templadas en las formas y con un contenido sexual menos explícito, mientras que lo africano cargaría con el potencial más expresivo y emocional de la danza; aquí la carga sensual sería muchísimo más evidente. La pugna entre estos dos modelos se puede rastrear en la historia del género musical de Hollywood determinando, de forma clara, las diferentes etapas a las que hicimos referencia con anterioridad y la relación que se establece entre la tradición musical predominante en cada momento y su peculiar modo de expresar el amor.

\section{CON ALAS EN LOS PIES.}

El impacto de Astaire en la historia del musical es, sin duda, uno de los más notables. No era un simple bailarín de claqué, sino un artista en constante búsqueda de un estilo donde lo tradicional pudiera convivir con lo nuevo. Su genialidad consistió en "no poner barreras entre las diferentes formas de bailes"19 y lograr destilar una maniera propia donde al claqué se unía el ballet y los bailes de salón. No obstante, ese estilo personal todavía tenía mucho más que ver con los bailes europeos que con la cultura popular americana. Los modos de Astaire eran "populares" en la medida que eran más naturales y espontáneos ${ }^{20}$ que los del ballet clásico, pero no así para el público americano. A éste, los movimientos de Astaire resultaban aún demasiados "europeos". En estos términos ha de entenderse la afirmación de Gene Kelly quien, años después, resumía sus diferencias diciendo: "cuando baila, Astaire representa la aristocracia y yo, al proletariado" 21.

Las coreografías de Astaire aparecen dominadas por la verticalidad, siempre meditadas, siempre contenidas. Ideadas con la razón, éstas se caracterizan por su sobriedad y precisión. No existen florituras en sus movimientos; son claros y diáfanos sus recursos expresivos. Los brazos sólo rinden tributo al equilibrio, no a la expresión. Los pasos de la danza se encadenan unos con otros casi sin pausa, formando un todo

\footnotetext{
18 DRIVER, I.: op. cit., pág. 96. En realidad, las raíces de toda la música popular americana se nutren de las aportaciones llegadas desde el otro lado del Atlántico. A propósito de esta influencia, Angela McRobbie destaca cómo "Los pasos del musical de Hollywood están tan en deuda con la cultura afroamericana como aquellos otros que, desde los años 50 hasta la actualidad, han sido copiados por generaciones de jóvenes blancos en clubs y salas de baile. Incluso en el análisis más superficial de las secuencias de intérpretes negros, sale a relucir la deuda que con ellos tienen contraída Fred Astaire, Gene Kelly, Ginger Rogers y muchos otros. Al igual que en los bailes sociales, existe un proceso lento en el que los estilos de danza afroamericanos son asumidos, adoptados y difundidos por los bailarines y artistas". "Dance Narratives and Fantasies", en DESMOND, J. C. (ed.): Meaning Motion. New Cultural Studies of Dance, Durham/Londres, Duke University Press, 1997, pág .215

19 DRIVER, I.: op. cit., pág. 106.

20 La espontaneidad era sólo una ilusión. Fred Astaire era un artista meticuloso, obsesionado con la perfección y, antes de filmar una escena, ensayaba sus números de baile hasta la extenuación.

21 Cit. DRIVER, I.: op .cit., pág. 165.
} 
continuo y armonioso. Cuando la pareja baila evoluciona con delicadeza, con una gracia y una elegancia que los acerca a los dioses. Platón en El banquete describía como al alma inflamada de amor le brotaban alas en la espalda. Como ningún otro Astaire expresó la ligereza y exquisitez del sentimiento, en formas de envolventes movimientos, pero a él, como a un moderno Apolo enamorado, las alas le nacían en los pies.

Casi todos los argumentos de las películas de Fred Astaire se hilaban en torno a los números que Hermes Pan y él mismo ideaban y preparaban. Las escenas de baile eran siempre filmadas, casi por completo, en un plano largo y en una toma continuada. Se pretendía con ello que los espectadores pudieran observar el movimiento completo de los bailarines dando una sensación de espontaneidad que escondía semanas de ensayos previos. En brillantes e inmensos decorados art decó concebidos por Van Nest Polglase, la aparente frescura de aquellas coreografías hicieron que las evoluciones de Astaire y su pareja transmitieran la existencia entre ellos de una complicidad inigualable. Tal era la compenetración que irradiaban sus apariciones en la pantalla que para Arlene Croce, crítico de danza, en estos filmes "el baile se transforma en una especie de vínculo de intensa emoción entre un hombre y una mujer. (...) Astaire tuvo algunas buenas parejas de baile, pero sin Rogers era un mundo con sol, pero sin luna"22.

Pero no todo el éxito de la pareja radicaba en su más que manifiesta afinidad. Las coreografías no constituían elementos autónomos, malavenidos con el resto de la trama. No eran simples ejercicios de destreza concebidos, al menos no únicamente, para deslumbrar a los espectadores, sino que, como el propio Astaire reconoció, cada número comunicaba una historia. No obstante habría que hacer una matización. Es evidente que sus escenas de baile con Rogers formaban parte del argumento, pero no es menos cierto que sus números aún no eran totalmente narrativos.

La escena de "Cheek to Cheek" de la película Sombrero de Copa (Mark Sandrich, 1935) es paradigmática no sólo del estilo depurado de la pareja formada por Fred Astaire y Ginger Rogers, sino de cómo en estos musicales se representaba el cortejo amoroso. Rick Altman en The American Film Musical hace una observación interesante con respecto a los filmes que ambos protagonizaron; y así explica cuál es el motivo que convierte cada encuentro en un campo de batalla electrificado por la tensión sexual. "Típicamente, del primer contacto entre ambos Ginger encuentra que tiene, simultáneamente, una razón para caer enamorada de Fred y un buen motivo para odiarlo. El es afable, con talento, diferente a otros hombres, pero, al mismo tiempo, es vanidoso, pagado de sí mismo, poco serio y rayando en lo irrespetuoso"23.

El relato del cuarto encuentro cinematográfico de Fred y Ginger es, en algunos elementos, seguidor de las reglas del amor cortés. Como ocurría entonces, también en Sombrero de Copa la pareja se enmarca en una relación a tres ${ }^{24}$. Es cierto

22 Cit. Ibídem, pág. 129.

23 ALTMAN, R.: op. cit., pág. 161.

24 MARKALE, J. : op. cit., pág. 115. 
que este triángulo sólo es fruto de un malentendido, prolongado con brillantez a lo largo de toda la película, que juega con la posibilidad de estar ante la representación de un amor adúltero. La bella modelo Dale Tremont (Ginger Rogers), tras conocer al astro de la comedia musical americana Jerry Travers (Fred Astaire) lo toma, erróneamente, por el marido de su mejor amiga Magde (Helen Broderick). A partir de esta confusión las escenas se suceden mostrando los avances enamorados de Jerry y los rechazos, cada vez más débiles, de Dale. Infatigable, movido sin saberlo por aquel precepto del código del amor cortés donde se señalaba que "una conquista fácil quita el valor al amor, una conquista difícil le da precio"25, el bailarín desplegará todos sus encantos para quebrantar las resistencias de su amada.

La famosa escena donde Fred Astaire y Ginger Rogers interpretan y bailan el tema "Cheek to Cheek" es ilustrativa de cómo se representó el amor en el cine musical de los treinta. Irving Berlin, en la cresta de su popularidad, compuso esta melodía ex profeso para la película. Su letra, luminosa y clara, habla de los embriagadores efectos del amor ${ }^{26}$. Ante la presencia de la amada, el amante se siente transportado hasta el cielo, nada hay comparable a la posibilidad de danzar, mejilla contra mejilla, junto a la amada. La superación de la distancia física a través del baile se entiende como el máximo anhelo del loco enamorado.

La secuencia presenta tres momentos diferenciados. El espacio físico del primero de ellos se descubre sobre la terraza abierta de un local veneciano al que un movimiento de grúa nos acerca suavemente. Magde y Dale, sentadas a la mesa, ven a aparecer a Jerry que, sin pudor, se acerca hasta ellas. Para sorpresa de Dale, a Magde no le importan los requiebros amorosos que le dedica su supuesto esposo, e incluso los incita a salir a bailar y divertirse.

Justo en el instante que Jerry y Dale se levantan y sumergen entre las demás parejas que ocupan la sala de baile da comienzo el segundo momento, preludio necesario para el cortejo y la conquista. Aunque todavía Dale muestra ciertas reticencias, se deja llevar mientras continúa interrogando con la mirada a su despreocupada amiga. No entendiendo la extraña situación, superada por sus sentimientos, finalmente cede. Sólo entonces, la melodía de Berlin que hasta a ese instante había actuado como mero telón de fondo musical, adquiere protagonismo y se encarna en las palabras que Fred Astaire le susurra al oído de su compañera. "Estoy en el cielo", le dice

25 Ibídem, pág. 91.

26 Diane Ackerman en su libro Una historia natural del amor (Barcelona, Anagrama, págs. 324-325), subraya la importancia que el amor ha tenido en la música popular contemporánea hasta tal punto que casi se ha convertido en una obsesión en sus letras: "Raramente sonará una canción sobre el trabajo, o un estribillo que diga 'venga, a currar'. O una canción testimonio sobre los sacrificios que los padres han hecho para criar a sus hijos. Pero no hay canciones sobre las soldaduras metálicas o sobre lo divertido que es ir en trineo. Las canciones pop viviseccionan las relaciones humanas. Son la fuente básica de la educación amorosa de los adolescentes (...).En las canciones populares compartimos mitos e ideales sobre el amor. De un modo rudo, a veces casi en términos económicos, nos previenen de lo mucho que puede costarnos el amor. Pero también nos anuncian la maravilla que puede ser. Ofrecen consejos sobre a quién amar, cómo saber si es un amor verdadero o no, qué hacer si uno es traicionado, como soportar el desamor". 


\section{2: artículos Bailando nace el amor. El cortejo amoroso en el cine...}

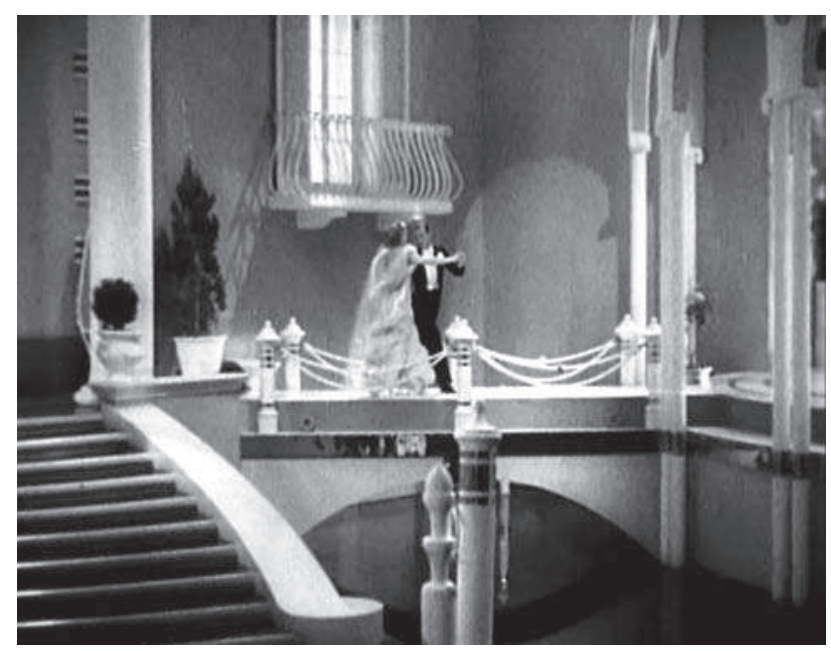

1. Sombrero de copa.

"y mi corazón late tan aprisa que apenas puedo respirar". Mientras Jerry seduce a Dale con su canto, de forma paulatina, casi imperceptible, la va desplazando desde el espacio público donde se encuentran hasta un espacio más íntimo, lo más alejado posible de ojos indiscretos [1]. El arrullo sensual y el galanteo se presentan así de forma más sutil, un amor aparentemente despojado de todo rastro de deseo sexual. La pulsión amorosa aparece más oculta, tan sublimada que podría pasar desapercibida salvo por las muestras de creciente entrega que refleja el rostro de la amada.

El clímax, el punto culminante viene marcado por el número de baile que se desarrolla bajo un templete de traza indefinible. En este tercer acto, que como suele suceder en todas las coreografías de la pareja fue rodado en plano general, la palabra ya no tiene cabida. Rendida la amada, sólo queda al amante expresar la intensidad de sus sentimientos a través de los movimientos del amor. Es aquí donde, de manera elegante y estilizada, la tensión sexual que ha perseguido a los protagonistas desde el comienzo del filme queda al fin liberada por medio de la danza. Esta última parte de la secuencia es interesante porque podemos distinguir en ella siete momentos y un epílogo que hilan un discurso cuya narración contempla el rapto, la prueba, el eco, la intimidad, la última resistencia, la rendición y el arrepentimiento. Curiosamente esas siete etapas están resueltas, desde el punto de vista del montaje, de manera sobria. Desde el respeto a la economía y la claridad del lenguaje del cine clásico, esta actuación musical se resuelve alternando muy pocos planos, apenas cinco, y contando tan sólo con tres posiciones de cámara. 


\section{Q: artículos Gonzalo M. Pavés}

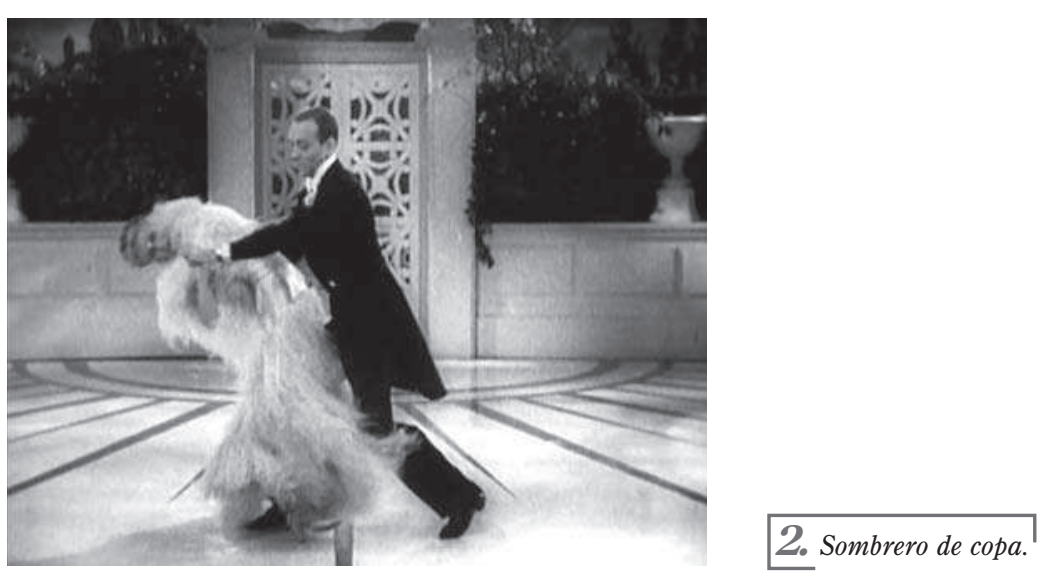

EL RAPTO.

Cuando el tema de Irving Berlin pasa a ser instrumental Jerry ha conseguido su objetivo: trasladar a Dale hasta ese espacio celestial donde, falto de respiración, palpita su corazón enamorado. Ese cielo que encabezaba con loca obstinación el estribillo de la canción está representado, de alguna forma, por ese templete semicircular, alejado de la muchedumbre y que está sólo conectado con el mundo por un estrecho puente que cruza un idealizado canal veneciano.

Este primer momento está rodado en un plano general largo que, con una pequeña panorámica, permite seguir la huida de los amantes hasta su nido de amor. Todavía el espectador está lejos; asiste en la distancia y su visión de la escena está mediatizada por la presencia de elementos interpuestos. A través de unas columnas pareadas que coquetean graciosamente con el orden jónico, se columbra a los bailarines. La escena es muy breve, los amantes entran en el recinto aislado y sólo amagan los primeros pasos; aún no se nos permite asistir como testigos directos a su ardor.

\section{QUIEBROS Y REQUIEBROS.}

El cambio de plano acerca al espectador hasta la pareja. Manteniendo la centralidad y la simetría en la composición, el baile apenas se desarrolla en profundidad. Las frases de la danza son cortas, apenas esbozadas, la pareja evoluciona suavemente, casi siempre sobre un mismo plano, equidistante del fondo y de la posición ocupada por la cámara. Es el momento del acercamiento, las miradas todavía son esquivas. Asiendo con firmeza a Dale por la cintura, Jerry por dos veces mece el cuerpo dócil de su compañera [2]. 


\section{2. artículos Bailando nace el amor. El cortejo amoroso en el cine...}

3. Sombrero de copa.

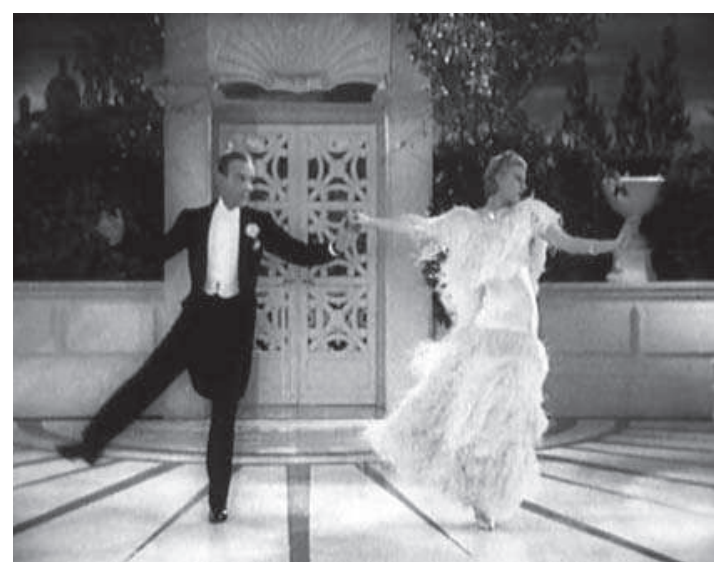

\section{El eco.}

El amante pone a prueba la entrega de su amada. Los movimientos de cada uno de los miembros de la pareja se reflejan en el otro como en un espejo. Bajo la atenta mirada de Jerry, Dale repite con fidelidad los dibujos que le propone su compañero. Satisfecho por la dulce devoción, los cuerpos se acercan, se abrazan, giran y se detienen para alcanzar casi la horizontalidad [3].

\section{LA INTIMIDAD.}

Coincidiendo con el primer crescendo del acompañamiento musical la cámara se retira pudorosamente para situarse de nuevo, aunque sólo por unos segundos, fuera del recinto del templete. El baile gana en intensidad; la pareja recorre ahora todo el espacio desde un extremo al otro.

\section{LA ÚlTIMA RESISTENCIA.}

El montaje vuelve a colocar al público cerca de los amantes. Hay un breve titubeo en Dale, un intento fugaz de recuperar la autonomía antes de la claudicación, un último esfuerzo por marcar las distancias. Hace el amago de separarse de Jerry, pero éste la persigue y nuevamente le impone el ritmo marcado por los movimientos de su cuerpo. Este quinto momento termina cuando Jerry atrapa por la cintura a su amada y la obliga, justo cuando comienza el segundo y definitivo crescendo musical, a seguirla en su danza que ahora adquiere profundidad espacial. 


\section{Q: artículos Gonzalo M. Pavés}

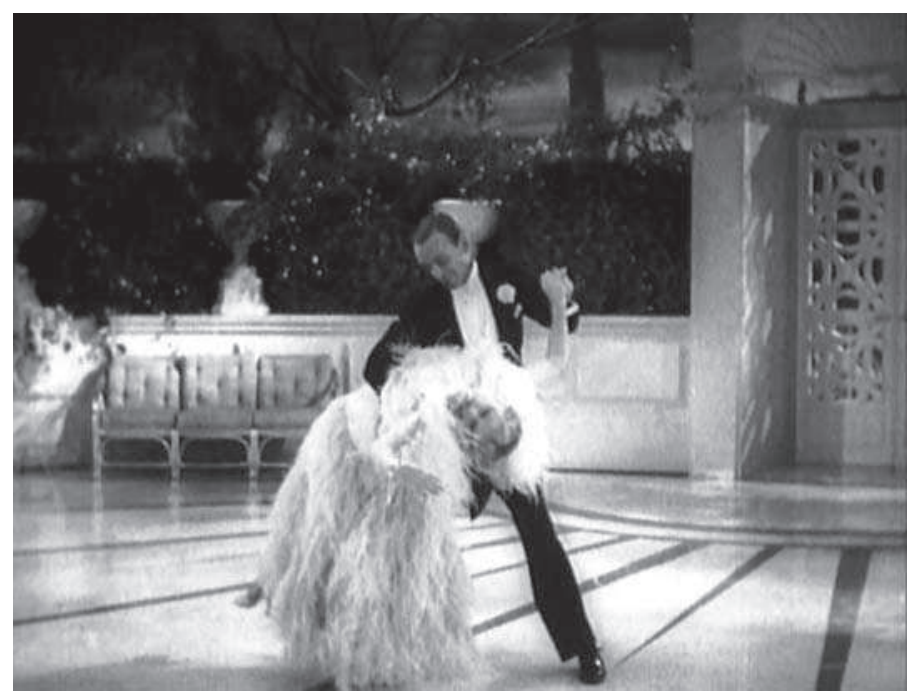

4. Sombrero de copa.

RENDICIÓN Y CONSUMACIÓN.

Manteniendo el plano general, la cámara abandona la centralidad que la había caracterizado hasta ahora. Es el momento del éxtasis, el baile se vuelve más acrobático y enérgico. Como las plumas que decoran su vestido, el cuerpo de Dale adquiere ligereza, también ella ha sido transportada hasta el cielo del amor, por eso evoluciona desmayada, sin voluntad, a expensas del deseo de su amante. El frenesí amoroso llega a su punto culminante cuando Jerry, inclinado sobre ella y abrazándola nuevamente por la cintura, la eleva despacio, suavemente [4].

\section{Arrepentimiento.}

El desenlace se inicia con un lento travelín hacia delante siguiendo las últimas evoluciones de la pareja hasta que, finalmente, ambos se apoyan en el muro que cierra el templete. La melodía da sus últimas notas y con ellas desaparece la magia, el dulce encantamiento que había nublado los ojos de Dale. Jerry retorna a la tierra convertido en el marido de su mejor amiga. El contacto visual que habían mantenido durante el baile se pierde, y la amada, arrepentida de su goce, da la espalda a su enamorado y abandona el espacio del amor [5]. 
1: artículos Bailando nace el amor. El cortejo amoroso en el cine...

BAILAR EN LA MGM.

Desde mediados de los cuarenta del siglo XX y durante toda la década siguiente, los musicales vivirán su verdadera edad de oro. Los bailarines Fred Astaire, Gene Kelly, Cyd Charisse, Judy Garland, el director Vincent Minelli, los compositores Irving Berlin, Cole Porter y Jule Styne, los coreógrafos Hermes Pan y Busby Berkeley, y el productor Arthur Freed confluyeron en los estudios Metro-Goldwyn-Mayer creando para esta productora toda una serie de musicales emblemáticos.

Tras la II Guerra Mundial Hollywood comenzó a ofrecer, para unos espectadores con paladares mucho más delicados y exigentes, unos productos más elaborados. La madurez del género supuso una mayor integración entre las canciones, el baile y los diálogos. De esta manera la narración se veía sometida a un flujo continuo donde historia y melodía convivían armónicamente. De este modo la danza dejaba definitivamente de ser un paréntesis en la trama, un extraño lapsus que no siempre encontraba debida justificación en el lógico discurrir de los acontecimientos. Pero también la posguerra significó el final del imperio del claqué que dejó, en estos años, de ser la forma principal en los espectáculos musicales. Para sus nuevos diseños los coreógrafos buscaron inspiración en elementos procedentes de los nuevos modos del jazz y en los movimientos, tal vez más complicados, pero también más libres, de la danza contemporánea, e introdujeron un estilo mucho más natural y espontáneo basado en las posturas y ademanes del baile popular americano. Todas estas influencias se combinaron para producir una nueva modalidad de ballet mucho más cercana a la interpretación y al movimiento natural del cuerpo.

Los encargados de la coreografía de la Metro tomaron prestado de ese nuevo ballet su concepto de baile como interpretación. En los musicales de entreguerras los personajes perdían su condición cuando comenzaba el baile, los actores suspendían la interpretación y se convertían en diestros bailarines. Se establecía así raros compartimentos estancos dentro de la historia, donde no existía comunicación entre el espacio de la actuación y el espacio de la danza. Ahora esas fronteras debían difuminarse, los actores al bailar debían volcar espontáneamente sus emociones, mantener vivo al personaje que encarnaban. Bailar en las producciones de la Metro suponía, por tanto, hacerlo de un modo narrativo y natural que, incluso, superaba las exigencias del nuevo ballet americano. Mientras en la danza clásica se buscaba ocultar todo rastro de esfuerzo físico y en la contemporánea se perseguía evidenciarlo, en los musicales de esta época se trataba de hacerlo parecer algo natural, sólo levemente diferente a los movimientos normales del cuerpo 27.

Esta nueva concepción del ballet trajo consigo una representación del amor menos encorsetada, aunque no por ello más explícita. La naturalidad perseguida en las actuaciones musicales supuso una mayor diversidad y una mayor "carnalidad". Frente a la monolítica representación del amor como un proceso con dos etapas, la

27 FEUER, J.: El musical americano. Madrid, Verdoux, 1992, pág. 26. 


\section{Q: artículos Gonzalo M. Pavés}

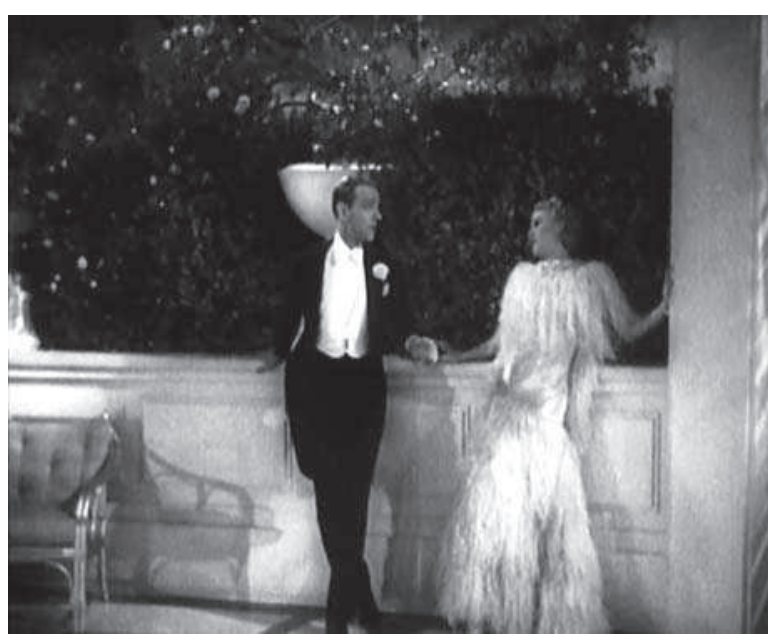

5. Sombrero de copa.

de fascinación y seducción, ahora los argumentos comienzan a incluir números donde se representan los diversos estadios del sentimiento.

Quizá como ninguna otra figura de la MGM, Gene Kelly contribuyó a la revitalización de las formas del género musical durante los años de posguerra. La fuerza, seguridad y energía que desprendía su imagen cinematográfica introdujo en el baile formas nuevas y un estilo muy característico y diferente al que había representado Fred Astaire durante el período de entreguerras. Si Astaire representaba la verticalidad y el clasicismo, la sobriedad y la elegancia en un mundo sutil de movimientos precisos, Kelly personificó la horizontalidad; una explosión de energía desatada igualmente eficaz se desató con él. Tras la aparente naturalidad de sus pasos también se ocultaba un artista concienzudo y exigente, aunque a menudo los personajes que encarnaba en la pantalla distaban mucho del elegante bailarín con sombrero de copa y chaqué. "Para Kelly bailar es una actividad tonta, infantil, una payasada, una expresión de la eterna juventud" 28 .

Movido siempre por ese inagotable brío adolescente, Kelly en sus películas hace algo más que bailar; por supuesto que hará en ellas alardes de destreza y habilidad, pero continuará interpretando a su personaje mientras canta y baila. Por esta razón en sus filmes se puede encontrar una variedad iconográfica del amor mucho mayor. Un claro ejemplo es Un americano en París (1951) de Vincent Minnelli. La historia de Jerry Mulligan, un pintor americano que trata de hacerse un hueco en el bohemio mundo de los artistas parisinos, y de Lise Bouvier, una joven francesita atada por su compromiso con un hombre mayor, es interesante por la manera en que se expresan las emociones y los distintos estados del amor. El momento de euforia

28 ALTMAN, R.: op. cit., pág. 57. 
del amante cuando se ve correspondido se ve muy claramente en el número musical que comparten Gene Kelly y Oskar Levant (Adam Stock, en el filme) en el que ambos interpretan la canción Tra-la-la-la (This time is really love) de George e Ira Gershwin. En el relato este número sigue a la escena en que Jerry, tras numerosos intentos, consigue una cita con la titubeante Lise. Mientras Adams Stock trata de ajustar una nueva composición en su piano, Jerry irrumpe en el apartamento henchido de felicidad ${ }^{29}$. La letra incide, como lo hacía Cheek to Cheek, en el estado que envuelve al enamorado cuando adivina próximo el momento del encuentro con la amada [6]. Nuevamente el cielo aparece en las estrofas como ese lugar ideal a donde es transportado el amante inflamado por las flechas del amor. Jerry compara a Lise con un soplo de primavera, con ese aire nuevo que acelera los latidos del corazón. Arrebatado por la magia del amor, movido por un frenesí irrefrenable, Jerry proclama a los cuatro vientos: “iEsta vez es realmente amor!”, mientras no puede evitar tararear, cantar y zapatear. Lo interesante es que Kelly no sólo habla de ello, sino que todo su cuerpo, sus gestos, sus manos, sus pies comenzarán a celebrar los efectos del amor describiendo movimientos por toda la habitación [7]. En un arrebato incontrolado, casi báquico, Kelly baila claqué sobre el piano y juega, con la punta y el talón de sus zapatos, con el quicio de la puerta para terminar ofreciendo, no sin dejar de hacer el payaso, toda una muestra de su virtuosismo como bailarín.

El encuentro entre los dos enamorados se produce de noche, a las orillas del Sena. Allí se representa, nuevamente a través del baile, otro de los momentos del amor, ese momento de indecisión en el que los amantes, a pesar de sentirse atraídos el uno por el otro, están atados por sus circunstancias. Jerry sabe que su carrera depende de Milo Roberts, una rica mujer madura, marchante, que le puede abrir las puertas del mercado del arte. En la película se insinúa que Milo tiene por Jerry un interés más que profesional, pero éste sólo se deja querer. Será Lise la que encarne el "sí, pero no" durante este número musical. Es Lise la que se ha comprometido con un hombre mayor, Henri Baurel. Más que un novio, Baurel ha sido siempre para la joven Lise su protector, un hombre con el que siente en deuda por haber cuidado de ella tras haber perdido a sus padres durante la guerra. Jerry encuentra en los ojos de Lise el auténtico amor de su vida, Lise también, pero el lastre de su compromiso es mucho mayor.

Sin lugar a dudas, de todos los números musicales de la película, éste es el más romántico y tierno. En esta escena, en la que Lise y Jerry cantan y bailan "Our love is here to stay", se representa de forma magistral las dudas de la protagonista. Casi sin palabras, recurriendo a los pequeños gestos, a la música y al lenguaje corporal, el guión de Alan Jay Lerner y la puesta en escena de Minelli consiguen captar hasta los más pequeños matices emocionales de la situación. La pareja no se

29 La violenta perturbación emocional que llamamos enamoramiento (o atracción), según Helen E. Fisher, podía iniciarse en una pequeña molécula llamada feniletilamina, o FEA. Conocida como la amina excitante, la FEA es una sustancia localizada en el cerebro que provoca sensaciones de exaltación, alegría y euforia. (FISHER, H.E.: op. cit., pág. 49). No cabe duda que Jerry Mulligan, por los efectos que se manifiestan en la coreografía de esta escena, ha sufrido una importante descarga de esta "amina excitante". 


Q: artículos Gonzalo M. Paves

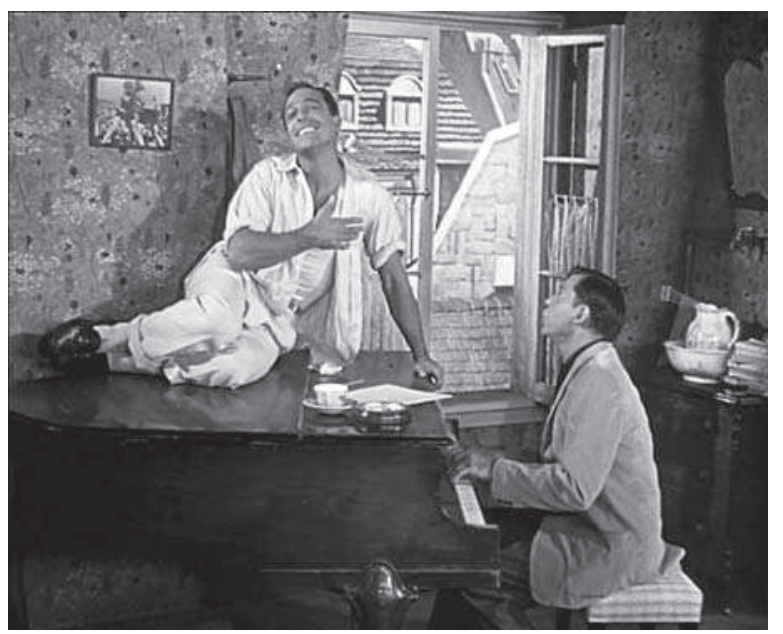

6. Un americano en París.

conoce bien todavía y, mientras se dirigen hacia el río, Jerry nervioso habla sin parar de sí mismo. Lise interviene de tanto en tanto; su mirada se mueve distraída, pero cuando se detiene en los ojos de él lo observa sonriendo.

La escena comienza con ellos sentados al borde del río. La posición de ambos es significativa, en un mismo plano la joven aparece arriba, sobre el muro, y Jerry abajo, sentado en el suelo. La disposición de los amantes habla de la distancia emocional que existe todavía entre ellos. Jerry es más terrenal, más instintivo, por eso yace cerca de la tierra; hace tan sólo unos instantes la ha invitado a vivir la noche intensamente [8]. La figura de ella, vaporosa y ligera, sin embargo, se delinea sobre el cielo de la noche. Es una extraña diagonal, porque no se miran, sus ojos parecen perdidos en el vacío, tratando de columbrar entre la niebla el mundo ideal donde ese amor que sienten es posible. Lise no cruza su mirada con su enamorado porque teme lidiar con sus sentimientos encontrados. Henry Baurel, invisible, flota a su alrededor como un fantasma. Lise no sabe si abrir las puertas a un mundo nuevo o renunciar a él hasta quedarse petrificada 30 .

Inquieto por la lentitud de sus avances, Jerry trata de conquistar nuevos terri-

30 Para Francesco Alberoni existen en este tipo de situaciones dos tipos de renuncia, la egoísta que se hace para evitar un dolor, y la altruista, aquella en la que las personas renuncian a su amor para no hacer sufrir a alguien que aman. "La renuncia, en todo caso, es siempre la alternativa que prefiere lo viejo a lo nuevo, la institución al estado naciente. Con este gesto el sujeto realiza un acto moralmente gravísimo. En efecto, e estado naciente es un contacto con lo absoluto, y es bajo su luz que incluso los precedentes objetos de amor adquieren valor. Una vez roto el contacto con el objeto amado, también esos amores, estos deseos desaparecen o se debilitan. En el caso de la renuncia egoísta se genera una sensación de soledad, de vacío total. Pero en el caso de la renuncia altruista el efecto es aún más devastador porque (...) el sujeto se vuelve incapaz de amar incluso a aquellos por los que se ha sacrificado (...) Todo se vuelve vacío, carente de valor, espectral. Par actuar sólo puede copiar los gestos de los demás, repetir lo que ha aprendido, por pura costumbre. Ya no tiene sentimientos verdaderos. Los pone en escena como un actor. Se siente un autómata, 


\section{2. artículos Bailando nace el amor. El cortejo amoroso en el cine...}

7. Un americano en París.

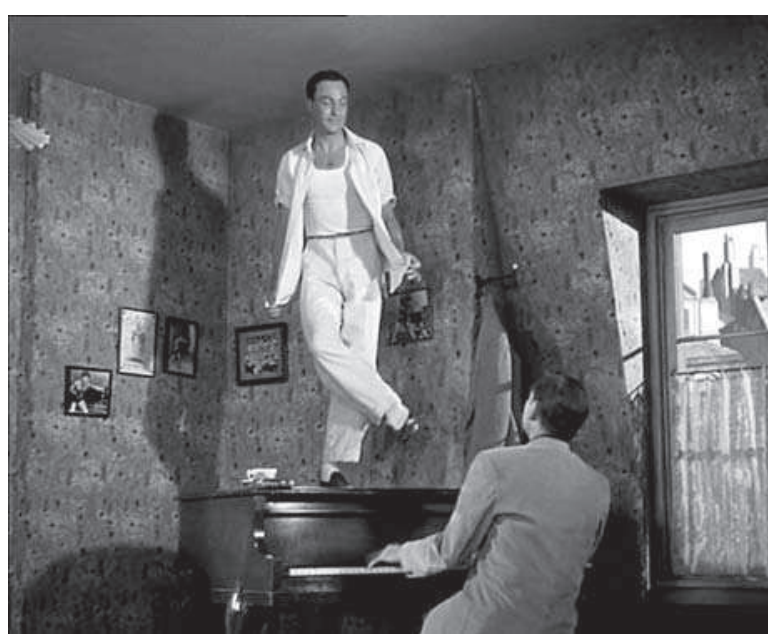

torios. Tres son sus intentos. La primera barrera se rompe cuando se levanta, se sienta junto a ella y le pide que le cuente algo de su vida. Lise vuelve a escapársele como la arena entre los dedos: "Prefiero seguir escuchándote, no me gusta hablar sobre mí misma". Inmune al desaliento, Jerry lo intenta una segunda vez. Distraídamente toma y acaricia la mano de Lise; a ella no parece importarle hasta que toma conciencia y la retira bruscamente. Jerry entonces le dice: "No sé si eres una chica misteriosa o un agua quieta y poco profunda, pero te diré una cosa, si te hubiera conocido antes sabrías lo atractiva que eres, y no me estoy burlando de ti". Para Lise la conversación se está volviendo demasiado comprometida, necesita tomar distancia, por eso se levanta y se aleja desapareciendo fuera del plano. Decía Shakespeare que "si la música es el alimento del amor, seguid tocando" 31 . Tal vez por esta razón Jerry comienza a cantar suavemente, tratando de atraerla de nuevo con la letra de la canción, intentando disolver sus dudas y convencerla de la naturaleza verdadera de sus sentimientos. "Está muy claro", dice la primera estrofa, "nuestro amor está aquí para quedarse. No por un año, sino para siempre y un día". Al principio, Lise se muestra indecisa y Jerry tiene que persuadirla para que baile con él, lentamente logra que se relaje y comience a manifestar sus sentimientos de manera más abierta. Como es habitual en estas escenas románticas, al terminar la palabra, da comienzo el baile. Gene Kelly no utiliza el claqué para seducir, su cuerpo describe pasos que invita a que repita su pareja.

A través de la coreografía también se expresan los temores y las dudas de

una marioneta. Es la petrificación. El único sentimiento verdadero, profundo, es la nostalgia de una realidad perdida". ALBERONI, F.: Te amo. Barcelona, Círculo de Lectores, 1997, págs. 160-161.

31 SHAKESPEARE, W.: La noche de la Epifanía, Acto I, Escena I. 


\section{Q: artículos Gonzalo M. Pavés}

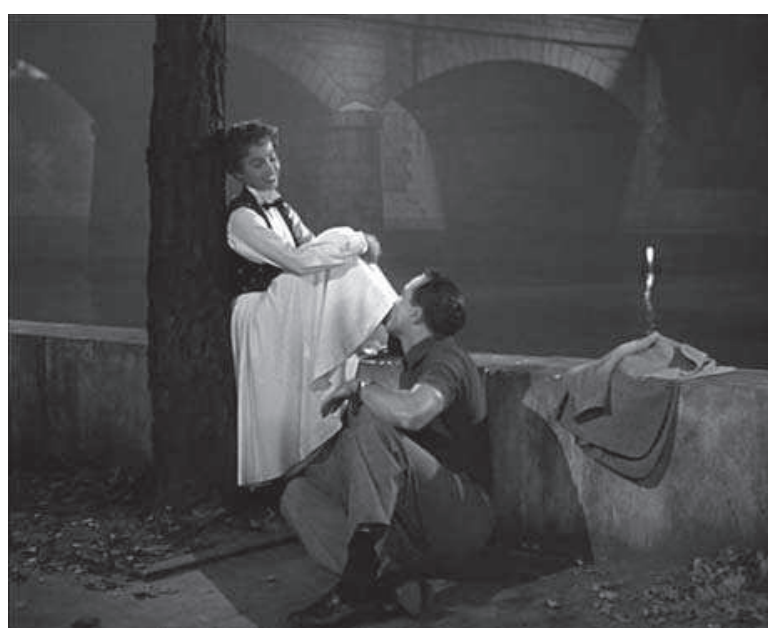

8. Un americano en París.

Lise. Durante todo el baile se produce un bello tira y afloja en el que ella va y viene; a veces acepta los movimientos de su amante y es entonces que, desaparecidas las dudas, se aprecia la sintonía física entre los dos jóvenes enamorados. Una y otra vez, se acoplan, se entienden, para luego separarse nuevamente [9]. Tierna y líricamente, ambos expresan sus emociones hilvanando el dramático y arremolinado clímax de su coreografía. Ambos evolucionan, girando uno alrededor del otro, en un crescendo de música y movimiento que concluye con un abrazo y un beso, apenas esbozado. A continuación, los amantes se alejan de la cámara y, cogidos de la mano, se pierden en medio de la niebla mientras la melodía languidece y se hace el silencio. Es entonces cuando Lise, de repente y sin dar explicaciones, echa a correr recordando que ha quedado en asistir al teatro para ver a su novio en una nueva actuación. Pero antes de irse Jerry le arranca la promesa de una nueva cita.

\section{EL AMOR Y SEXO EN EL MUSICAL CONTEMPORANEO.}

En los años cincuenta el panorama de la música popular se vio sacudido por la aparición del "rock and roll". Los orígenes del término están rodeados de un halo misterioso. Según la leyenda, Alan Freed, locutor y pinchadiscos dio a sus discos de "rhythm and blues" el nombre de rock and roll sólo para que no tuvieran connotaciones raciales. Irónicamente, una frase que buscaba respetabilidad equivalía a "sexo" en la comunidad afroamericana. Efectivamente, el rock era energía instintiva impulsada por la testoterona; era sexual, atlético, estimulante, pero básicamente era swing con un atrevimiento y frenesí sexual nunca antes visto. Los bailarines se movían de un modo que, mucha gente, tachó de provocador. Elvis Presley, cuya primera actua- 


\section{Q: artículos Bailando nace el amor. El cortejo amoroso en el cine...}

9. Un americano en París.

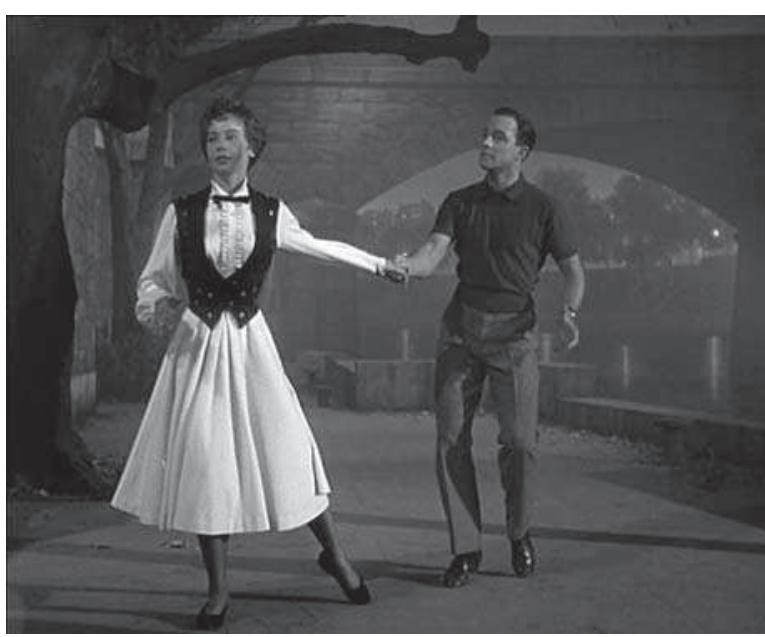

ción para el show televisivo de Ed Sullivan fue rodada en un discreto plano medio, siempre decía que, la sugestiva rotación de caderas que le hizo famoso tan sólo era una respuesta a cómo le hacía sentir la música.

Esta nueva forma musical impuso sus conceptos, impregnando toda la cultura juvenil y afectando, como no podía ser de otro modo, también a los musicales, cuyos modos y estilos de baile van a quedar totalmente anticuados y obsoletos. Durante el cine contemporáneo muchas películas del género van a estar influidas por la cultura juvenil y sus preocupaciones. El estreno de filmes como West Side Story (1961), Jesucristo Superstar (1973), The Rocky Horror Picture Show (1975) Tommy (1975), Hair (1979), Flashdance (1983), Footloose (1984), Dirty Dancing (1987) o Moulin Rouge (2001) por ejemplo, constata una tendencia cinematográfica dentro del género que cuenta con referencias musicales distintas a las de décadas anteriores. Es cierto que se continuarán haciendo musicales al estilo clásico como My Fair Lady (1964), El doctor Dolittle (1967), Oliver (1968), Hello Dolly (1969) o El valle del arco iris (1968), pero la industria, que sabía muy bien que sus espectadores eran principalmente jóvenes y adolescentes, trató de adaptarse así a los cambiantes gustos de su público mayoritario, ofreciéndoles espectáculos que sintonizaba con esta nueva sensibilidad musical. Una sensibilidad que persiguió la expresión natural de las emociones y que estaba influida, de forma mucho más acusada, por los ritmos y melodías afroamericanas.

Las coreografías, inspiradas en movimientos con una evidente carga erótica, no dejan ya margen para las metáforas o las ambigüedades. El sexo se convertía así en el tema central de las letras y la música de muchas composiciones; "las canciones de amor reflejaron repentinamente la revolución social, el sexo desinhibido, 


\section{Q: artículos Gonzalo M. Pavés}
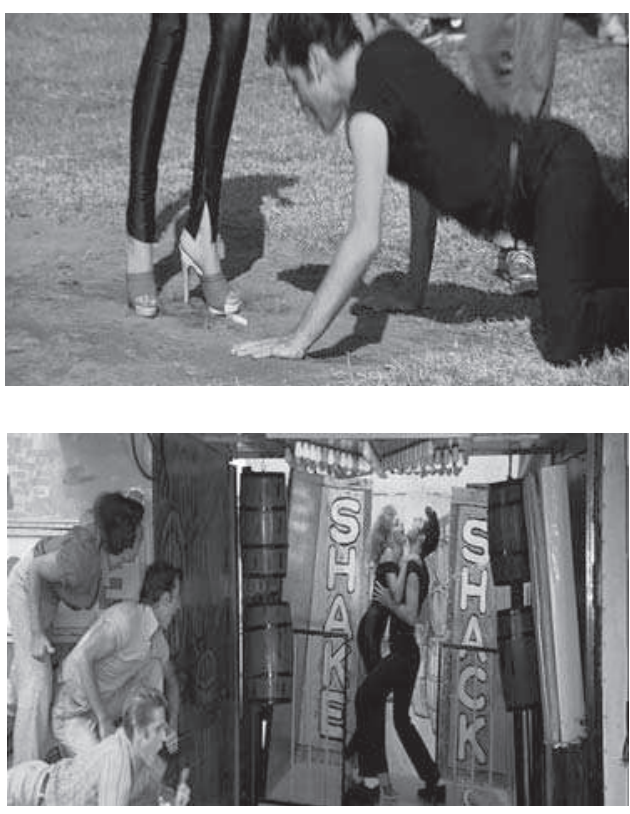

\section{Grease. \\ 11. Grease.}

el amor como camino de perfección, y el rechazo de los tabúes de la clase media. El amor era otra vez una religión, una que podía salvar al mundo, como proclamaban los Beatles y otros grupos"32.

Inspirado en un musical de Broadway de 1972 creado por Jim Jacobs y Warren Casey, la película Grease (Randal Kleiser, 1978) se convirtió en uno de los grandes éxitos de taquilla de aquella temporada. Concebido como un homenaje, lleno de nostalgia, a la época dorada del rock and roll, la trama giraba en torno a los personajes de Sandy y Danny que, tras un breve romance de verano, vuelven a encontrarse por sorpresa al comenzar el curso en el instituto. La reputación de chico duro que Danny tiene en el centro le obligará a ocultar sus sentimientos, pero Sandy y sus amigas idearán un plan para atraerlo. La ingenuidad y dulzura de la chica no casa muy bien con el ambiente varonil del joven protagonista por eso, para no perderlo, Sandy decide transformarse en una joven rockera, activa, resuelta y agresiva. Esa metamorfosis queda completada en el número musical que ambos interpretan, casi al final del filme, y en el que cantan y bailan la canción You're The One That I Want.

Nada queda ya de la elegancia y el glamour de Fred Astaire, ni de la sutileza con la que el cine clásico y la danza representaban los sentimientos o, incluso, la atrac-

32 ACKERMAN, D.: op. cit., pág. 326. 
ción física. En esta escena que se desarrolla en los festejos de graduación, la mojigata Sandy aparece ante el sorprendido Danny Zuko como una gata desafiante vestida de cuero. Frente a la niña buena, de calcetines blancos y lazos de colores en el pelo, la nueva Sandy se ha soltado la melena, enfundada en unos pantys de cuero negro y encaramada en unos zuecos de tacón rojos. Si gracias al amor brotaban alas en los pies de Gene Kelly y Fred Astaire, nada de eso percibimos ya en Travolta. La lírica sutileza ha desaparecido y la carnalidad de los movimientos es evidente. Danny se contonea, mueve las caderas con frenesí y, antes de caer de rodillas ante su insinuante compañera, no puede evitar exclamar: "Siento escalofríos que se multiplican y estoy perdiendo el control, porque la fuerza que me suministras es electrificante". En un plano significativo, Danny aparece junto a los zuecos rojos de Sandy y esta imagen de referencias sin duda fetichistas, nos habla de la posición de sumisión del amante que se encuentra a merced de sus más bajos instintos [10]. Al contrario de lo que sucedía en los musicales clásicos, ella ya no encarna un ideal, sino un deseo personificado. Esta posición de dominio se traduce en el baile en un intercambio de roles. No es él sino ella la que dirigirá la acción, será Sandy la que controle los pasos y movimientos de la coreografía, dando en muchas ocasiones la espalda a su compañero que la sigue como poseído por el mágico olor de las feromonas. Danny se someterá y reaccionará, casi como un autómata, imitando los pasos propuestos por su compañera de baile. Pero ese vasallaje se verá además subrayado por la actitud sexualmente desafiante que adopta Sandy: "Más vale que te preparares" le espeta, mientras lo conduce al interior de una de las atracciones de la feria, "porque necesito un hombre que me pueda satisfacer". Es reseñable además que, hasta casi el final del número musical, no haya contacto físico entre ellos. Esa aproximación sólo se produce cuando, en un espacio bamboleante ${ }^{33}$, se agarran el uno al otro describiendo con sus caderas movimientos con claras connotaciones sexuales [11]

\section{EL FINAL DEL ESPECTÁCULO.}

Ante el amor, dice Diane Ackerman, a veces actuamos como pequeñas criaturas temerosas; nos asusta más que la violencia, incluso mucho más que el odio. Es algo comprensible; cuando amamos hacemos entrega de nuestra más íntima vulnerabilidad, "equipamos a alguien con los cuchillos más afilados, nos desnudamos

\footnotetext{
33 Estas referencias sexuales están, a nuestro juicio, resaltadas por las palabras SHAKE SHACK que se pueden leer en las paredes de este espacio. Unidas hacen referencia al nombre por el que es conocida esta plataforma en las ferias de atracciones, y cuya característica principal es que su suelo está continuamente balanceándose de un lado para otro. Pero por separado SHAKE es un verbo que en inglés significa "moverse adelante y atrás o arriba y abajo en movimientos cortos y rápidos, o hacer que algo o alguien haga esto" y SHACK, además de aludir a una pequeña construcción hecha con pequeños trozos de madera, metal u otros materiales, cuando va a acompañado de la preposición UP se convierte en un verbo que adquiere un curioso significado: "comenzar a compartir una casa con tu pareja sin estar previamente casado". En el contexto de esta escena no deja de ser llamativo.
} 
al completo, y luego le invitamos a acercarse"34. En realidad, el cine musical sólo estuvo interesado en los aspectos más luminosos del amor. Fiel al amor cortés medieval de cuyas fuentes bebía, el género se entretuvo en representar, con mayor o menor sutilezas según la época, los momentos de seducción y conquista. La rutina y el desamor eran alimentos propios del melodrama.

Con el musical se apostaba por construir un mundo de fantasía, alejado de las preocupaciones de la vida real. Oscar Wilde lo tenía muy claro cuando decía que necesitamos de estas bellas mentiras para seguir sobreviviendo. En el fondo, el cine el musical no es más que eso, una bella mentira, una invitación para dejarnos llevar en alas de la danza y del amor hasta ese cielo que Fred Astaire y Gene Kelly sólo alcanzaban con el ritmo loco de sus pies.

34 ACKERMAN, D.: op. cit., pág. 18. 